\title{
A Poetic of Beauty: Nature, Memory and Resilience in El Botón de Nacar/The Pearl Button (2015)
}

\author{
Una poética de lo bello: naturaleza, memoria y \\ resilencia en El Botón de Nacar (2015)
}

\begin{abstract}
Resumen
Uno de los pilares de la historia del documental latinoamericano es sin duda el director chileno Patricio Guzmán. Durante más de cinco décadas de producción fílmica ha dado cuenta de la historia política de Chile, específicamente se ha ocupado del significado de la dictadura chilena para el pasado, presente y futuro del país, además de su relevancia en el contexto latinoamericano. Sus películas representan sin lugar a dudas uno de los testimonios más relevantes de la historia del continente en el siglo XX con cientos de horas de grabación de los momentos más álgidos en el proceso de transición violenta entre el gobierno de Allende y Pinochet. Su propuesta fílmica dará un giro radical en sus últimas dos producciones: Nostalgia de la Luz ([2010] 2011) y El Botón de Nácar (2015), las cuales hacen parte de una trilogía -la última película está en proceso de producción-. Su propuesta estética es revolucionaria en el sentido de que resignifica la relación entre memoria e historia estableciendo una conexión entre naturaleza, cosmología y memoria histórica. En esta trilogía se ocupa por separado en cada película del desierto, el mar y la montaña, llevando al espectador a una reflexión que, a través del lenguaje poético y un tono meditativo, propone una nueva mirada de la historia y la memoria. En este ensayo analizo tres elementos que definen su película El Botón de Nacar y que abren las posibilidades a un nuevo tipo de reflexión teórica sobre el género del documental: la relación entre naturaleza, narración e historia, la historia entendida como memoria genealógica y el nuevo tipo de estética visual que el director está proponiendo, a la que llamo "poesía de lo bello".
\end{abstract}




\begin{abstract}
One of the pillars of the history of Latin American documentary filmmaking is undoubtedly the Chilean director Patricio Guzmán. During more than five decades of film production, he has given an account of Chile's political history, specifically dealing with the meaning of the Chilean dictatorship for the country's past, present and future, as well as its relevance in the Latin American context. His films undoubtedly represent one of the most relevant testimonies to the continent's history in the 20th century, with hundreds of hours of footage of the high points in the violent transition process between the Allende and Pinochet governments. His film proposal will take a radical turn in his last two productions: Nostalgia de la Luz ([2010] 2011) and El Botón de Nácar (2015), which are part of a trilogy - the latter film is currently in production. Its aesthetic proposal is revolutionary in the sense that it resignifies the relationship between memory and history by establishing a connection between nature, cosmology and historical memory. In this trilogy he deals separately in each film with the desert, the sea and the mountain, leading the viewer to a reflection that, through poetic language and a meditative tone, proposes a new look at history and memory. In this essay I analyze three elements that define his film El Botón de Nacar and that open the possibilities for a new type of theoretical reflection on the documentary genre: the relationship between nature, narration and history, history understood as genealogical memory and the new type of visual aesthetic that the director is proposing, which I call "poetry of beauty".
\end{abstract}

Keywords

Memory, Chile, Documentary, Dictatorship, Latin American Cinema, Nature.

"Water is an intermediary between the stars and us". The Pearl Button (Guzmán, 2015)

"A country without documentary film is like a family without a photo album," according to the Chilean director Patricio Guzmán. Documentary is the medium that allows a nation to preserve its memory, a visual arcade that becomes a mirror for a society that wants to recognize its own image. But why is this necessary? It contributes to the narration of the past - the photo album — and the building of the future. Additionally, the "documentary" can be seen as a reminder of the changes, the triumphs, the celebrations, the challenges and also the tragedies of an individual or in this case a social body, Chilean society.

1 "Un país sin cine documental es como una familia sin álbum de fotografías". From his official website: https://www.patricioguzman.com/es/. 


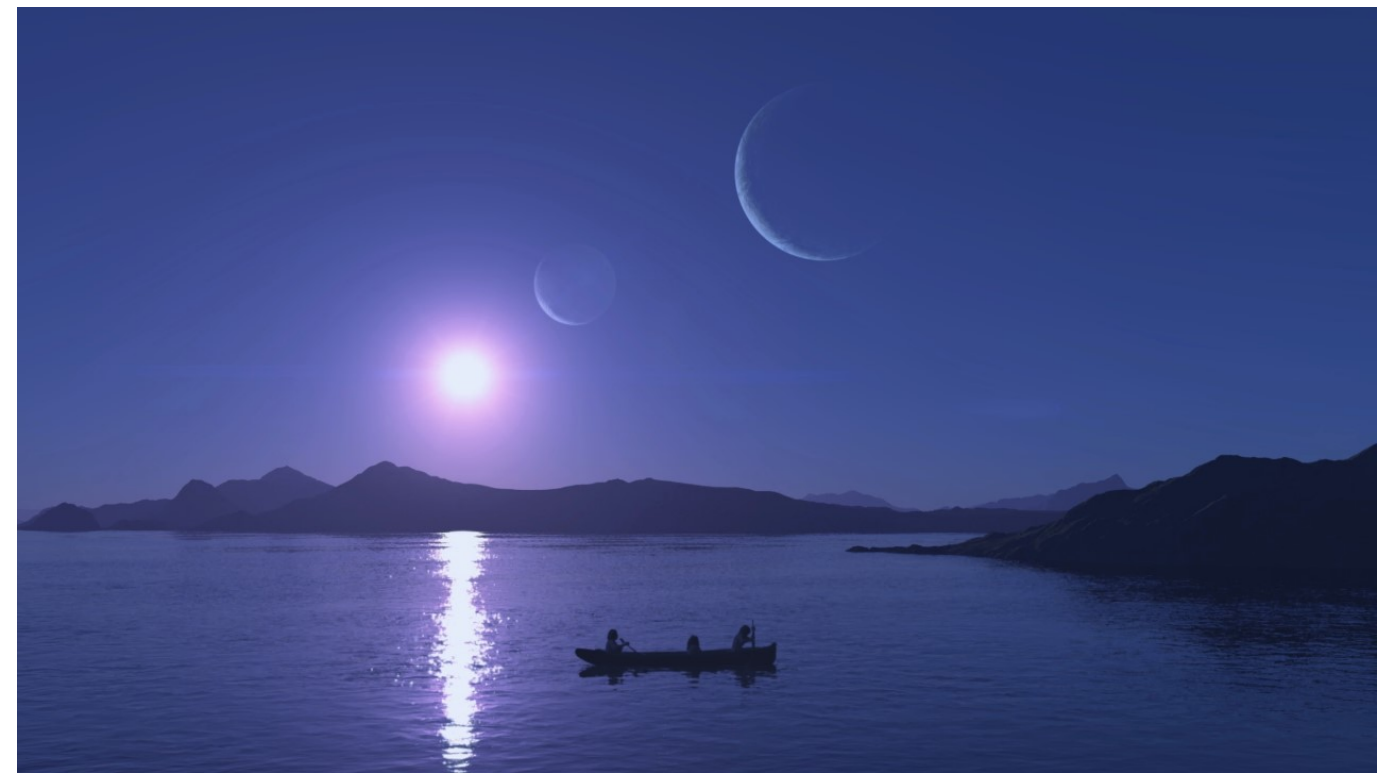

For Guzmán, the documentary is not an individual project but instead is the product of a collective memory. For him, some want to deny the image evoked from that memory, maybe because they want to avoid the horror of looking at themselves in that "album".

The Pearl Button (2015) is the second film, after Nostalgia for the Light (2011), in Guzman's trilogy portraying the history of Chile, specifically the history of the years before and after the 1973 coup d'état. Even though he has dedicated his film production of almost 50 years to the coup d'état, this trilogy—which finishes with Cordillera, ${ }^{2}$ where the protagonist is the Andes mountains-takes a very different approach than anything Guzmán has produced before. Guzmán says that he is looking for different and new narratives to tell the same story. Indeed, he is telling a much more complex story than the one he has been telling for the last five decades in his prolific film production. And yet very little in terms of scholarly production has been said about his last film: A Pearl Button. I argue that there are three elements that define his film and that opens the road to a new approach in

\footnotetext{
${ }^{2}$ This film was presented in the Festival de Cannes 2019.
} 
filmmaking: a poetic language, the role of nature in the film and history as a genealogical memory. I propose analyzing his movie The Pearl Button by a new lens that include these three elements, what I call a "poetic of beauty". This kind of poetic has a purpose: creating resilience.

\section{The Language of the film: A New Kind of Poetic Approach}

Patricio Guzmán's trilogy, The Battle of Chile (1975-1979), and most of his film productions are related to a very specific period in the history of the country, mainly the "Popular Unity" period of Salvador Allende's democratically elected government overthrown by the coup of General Augusto Pinochet's army in September 11, 1973. Without a doubt, Guzmán films constitute the most relevant visual archive of those years in Chilean history. ${ }^{3}$ The relevance of his documentaries for the construction of a historical memory has been extensively discussed. ${ }^{4}$

After tracing this solid trajectory, Guzmán has made a turn in his cinematographic and esthetic view. In 2010 the filmmaker started a new trilogy with the movie Nostalgia de la luz, Nostalgia for the Light, followed by El botón de nacar, The Pearl Button from 2015. Before this trilogy, his cinematic approach was closer to a journalistic view, using black and white images and interviews with the explicit purpose of communicating and denouncing what happened during the years of the military dictatorship. That is the case of one of his best known documentaries, The Obstinate Memory from 1997. The movie is about the search for the protagonists of the three movies that are part of the trilogy The Battle of Chile after 23 years. It traces the lives of the victims of the Pinochet regime and those who were active participants on the day of the coup, like Allende's bodyguards who gave testimony about the events of that fatidic September 11. The

${ }^{3}$ Other documentaries that focus on this topic are: The Tiger Leapt and Killed but He Will Die... He Will Die, Santiago Álvarez, 1973; Dialogues of Exiles, Raúl Ruiz, 1974; Chile: When Will It End?, David Bradbury, 1985; Images of a Dictatorship, Patricio Henríquez, 1999; National Stadium, Carmen Luz Parot, 2002; The City of Photographers, Sebastián Moreno, 2006; The Chicago Conspiracy, Subversive Action Films, 2010.

${ }^{4}$ Andermann and Campo are two examples of this scholarship. 
tone and rhythm of these documentaries are urgent, giving the impression that is necessary and impossible to evade the crucial information provided by the witnesses. The spectator perceives the documentary as an archive, a testimony of what "really" happened in those turbulent years of the dictatorship. Following Michael Renov categorization of what he calls "the fundamental tendencies of documentary", before his new trilogy Guzmán's film productions focus mainly in the first three tendencies:

\section{1) To record, reveal or preserve \\ 2) To persuade or promote \\ 3) To analyze or interrogate}

His new trilogy brings something very different. Art and poetry become protagonists, without putting aside a critique of the state but with a different kind of narration and approach. Trough stunning images of nature and a poetic language Guzmán portrays the history, histories and stories of Chile even before Chile was born as a nation, when for example the first inhabitants, "the pueblos del agua" dominated the Patagonia region. Different from them "we have lost our intimacy with the sea".

In his article "Toward a Poetics of Documentary" Michael Renov sustain that "to risk a poetics of documentary is to up the stakes yet again, since it is commonly supposed that the aim and effect of documentary practices must be [...] truth and only secondarily, if at all, pleasure" (14). Ironically pleasure, beauty and horror ${ }^{5}$ become a must in The Pearl Button. In his article Renov explains how Roland Barthes in "The Return of the Poetician" traces a genealogy for poetics trough Aristotle, Valery and Jakobson. The Greek poiesis means active making. Guzmán creates a film that focus on the exploration of the senses and the composition of a visual image that captures the viewer attention trough what I call

${ }^{5}$ Trough for example the detail description of the techniques used for torturing the victims of the military regime. 
"a poetic of beauty". The poetic approach develop by A Pearl Button is completely entangled with the political. But in this film the political message and the search for the ones responsible for the atrocities during the Pinochet years is secondary, the form, the images, the sounds, the pace creates a visual composition that seduces the viewer and goes beyond a pure political rational discourse. Nevertheless there is a critique of the abuse of power that characterizes crucial moments in the history of Chile.

The fourth fundamental tendency of the documentary explained by Renov is to express. Even tough in his film Guzmán creates a poetics of storytelling where the four elements appeared, the fourth one is the one that in this case encapsulates this film. "Moreover, the ability to evoke emotional response or induce pleasure in the spectator by formal means, to generate lyric power through shadings of sound and image in a manner exclusive of verbalization, or to engage with the musical or poetic qualities of language itself must not be seen as mere distractions from the main event (35)." For Renov though, the expressive dimension enhanced the communicative aim. But what Guzmán is doing in his film is far more radical, there is still a message to communicate but meaning is produce by the spectator, by being exposed to a visual composition that appeals to emotions, sensations, sounds, images and a poetic language.

I believe the director set the tone when he opens the second movie of the trilogy with the phrase of the poet, Raúl Zurita ${ }^{6}$ : Todos somos amigos de una sola agua. We are all friends of the same water. Is not a coincidence that Guzmán chose a poet to narrate some of the film's main episodes. The poetic language used by Zuritá combined with the poetic narration by the director himself resonates well with the breathtaking images of nature that, at the end of the movie, become the real protagonists, over and above the political history. Being friends of the same water means that there is an element that connects everything in the movie, an element essential for life - the same water that acted as an "accomplice" of the military regime "hiding" the bodies that were tortured and killed. The sea took

\footnotetext{
${ }^{6}$ Winner of the Premio Nacional de Literatura de Chile in 2000.
} 
Guzmán's first "desaparecido," a childhood friend who drowned in the same water that will bring back some of the other "desaparecidos" decades later. Telling that story Guzmán intertwines his personal story with the larger story he tells.

The sea was a cemetery, as the movie says, but the water also brought the bodies back and by doing so offered the opportunity of redemption. The presence of the actual body allows the families and the nation to give some kind of closure to the search of the "desaparecidos", even though that search actually will never had an end. Is impossible to find everybody and bring back all the bodies, sometimes only the objects can be witnesses of what happened. Here is where the pearl button is relevant, as the trace of the life of one of the victims.

On the other hand, the relevance of water in this documentary has another dimension, the narrator explains that as has been research by scientists, is very possible water makes life in the planet possible. According to one of the theories about the presence of water in planet earth, water could have been brought from the stars or other planets. The credibility of that theory is not the point here but instead its relevance for the argument the film is making. That argument has to do with a genealogical memory, meaning a memory that connects different episodes in the history of Chile as part of one big narrative that has to do with the origin of the cosmos and the millenary life of celestial bodies. If water is what makes human existence possible and it was brought from the stars, water is what connects humans with the big story of the universe.

"Everything is alive and has its spirit... Everything sounds... The universe is moving", this kind of statements set the tone of the film, intimate and personal, is attained through a voiceover -the narrator is Guzmán himself- that at first is exquisite and at some point becomes tedious. There is an obvious intention to force the spectator to take the time to observe, feel, hear and almost touch the elements, like water, and the objects, like the pearl button. The pace is slow and meditative. The script is full of metaphors, emphasis and different playful ways in which he uses the language.

Besides the poetic language in the script of the film and the poetic images, 
which through astonishingly beautiful landscapes stimulate the eye, there is an exploration of the senses that contribute to the poetic language of the film not limited to visual perception. The emphasis of the sense of hearing and the importance of listening carefully is profoundly relevant. The scenes where the spectator hears the sound of water falling or the breaking of ice have a beauty that participates in the composition of the poetic tone of the film. Such experimentation started with Nostalgic for the light, in which sound is also a protagonist. The sound of the huge telescopes is constant through that film, along with the sound of the wind in the desert.

Since water is the protagonist in The Pearl Button, as light and the desert were in Nostalgia for the Light, the film reflects on the importance of the sound that water makes. Everything that moves has a sound, and when water moves it makes not just one sound, but a complex collection of sounds that produce a symphony, as will be shown by the musician and anthropologist Claudio Mercado in the film, when he uses his voice to imitate the sound of the water. In this scene the narrator explains that Claudio learned from the natives the language of water, they believe the water is alive and has its own spirit. There are close-ups of drops of water, rivers and waterfalls and finally a long scene where, almost like an ancestral ritual, Mercado uses his voice to produce the "song" of the water, a complex and multiple ensemble of sounds with a multiple scale of tonalities that very rarely the spectator has been exposed to. He insists in the necessity of really listen, not just hearing. Something so familiar as the sound of water becomes strange and almost sub-real.

In a subtle way during the film water becomes an entity that has its own ways. This "personification" of water will open the path for several stories that come later: the story of the natives of the Patagonia region, nomadic populations that lived ten thousand years ago and that travelled from island to island "living in the water"; the story of the "civilization" and extermination in the nineteenth century of the natives that lived in that region; and the story of the bodies that were thrown in the sea by the Pinochet regime to hide the torturing of thousands of people. Water is thus a metaphor that Guzmán uses to refer to the flow of time. The 
water has memory and it is the water that brings back a pearl button that was attached to the clothes of one of the victims of the Pinochet regime. Is the thread of water that allows the connection of events and the tracing of memory.

Nature is, at the end, the only "entity" that can save Chilean society, and "humanity". Trough this romantic vision of nature, Guzmán reminds the viewer that water is a natural resource crucial for life; in that sense, its presence represents the presence of hope and resilience. The movement of water also has a meaning, water flows and that sense of constant movement allows life to continue, metaphorically brings a possibility of continuity even though it is hard to leave the past behind. What is at stake in the Pearl Button, different from his first trilogy, The Battle of Chile, is what I call a poetic of beauty that intertwines politics, social justice and the environment trough an exploration of the senses.

Different from his other films, with a meditative and more essayistic style, A Pearl Button is a sensorial experience, one where the exposure to close ups and panoramic views takes the viewer on a journey where colors, shapes and sounds are at the center. In broader terms we can say that A Pearl Button is about the importance of water in Chile. The movie starts with a close-up of a quartz that is more than 3000 years old. This scene is a long shot that has a black background and almost no sound. The director takes its time and wants the viewer to do the same, to see and not just watch, get immerse in the pace of the film and really observe the details of the material and the shape. At first it could appear like a gigantic ice mountain, and then we discover its real size. A drop of water is trapped inside this quartz, a thought that will lead us to the story of the film.

This long shot of the quartz where a simple object is transformed in a "sacred" object wants to play with the meaning of objects and how our mind label those objects, something so familiar becomes unfamiliar, eternal, infinite, an element of outer space. The language of the poet is present, not only in the words chosen by the narrator, but also present in the images of the glaciers, the sea, the water, the rivers, and the fascination he shows with different types of objects, natural or hand made. 
Each one of Guzmán's films is linked to a different element in nature: desert in the first, water in the second, mountains in the third. Water in the case of $A$ Pearl Button is not only an element, but also a landscape (the sea), a space where communities lived and through which they moved and a metaphor for flow, circulation, and memory. The film's innovative narrative and particular estheticwhich includes astonishing images of nature, a meditative tone and the stimulation of the senses through play with image, sound and rhythm - are captured by Kevin B. Lee's review, which calls it "a form of documentary art": "breathtakingly bizarre portraits of native peoples decked in elaborate body paint and masks stretch our ability to recognize the human, before these figures dissolve uncannily into spectral shots of galaxies." Lee calls Guzmán’s style a "free-flowing essayistic mode" that allows him "to weave together multiple modes of documentary: the picturesque, the political and the poetic."

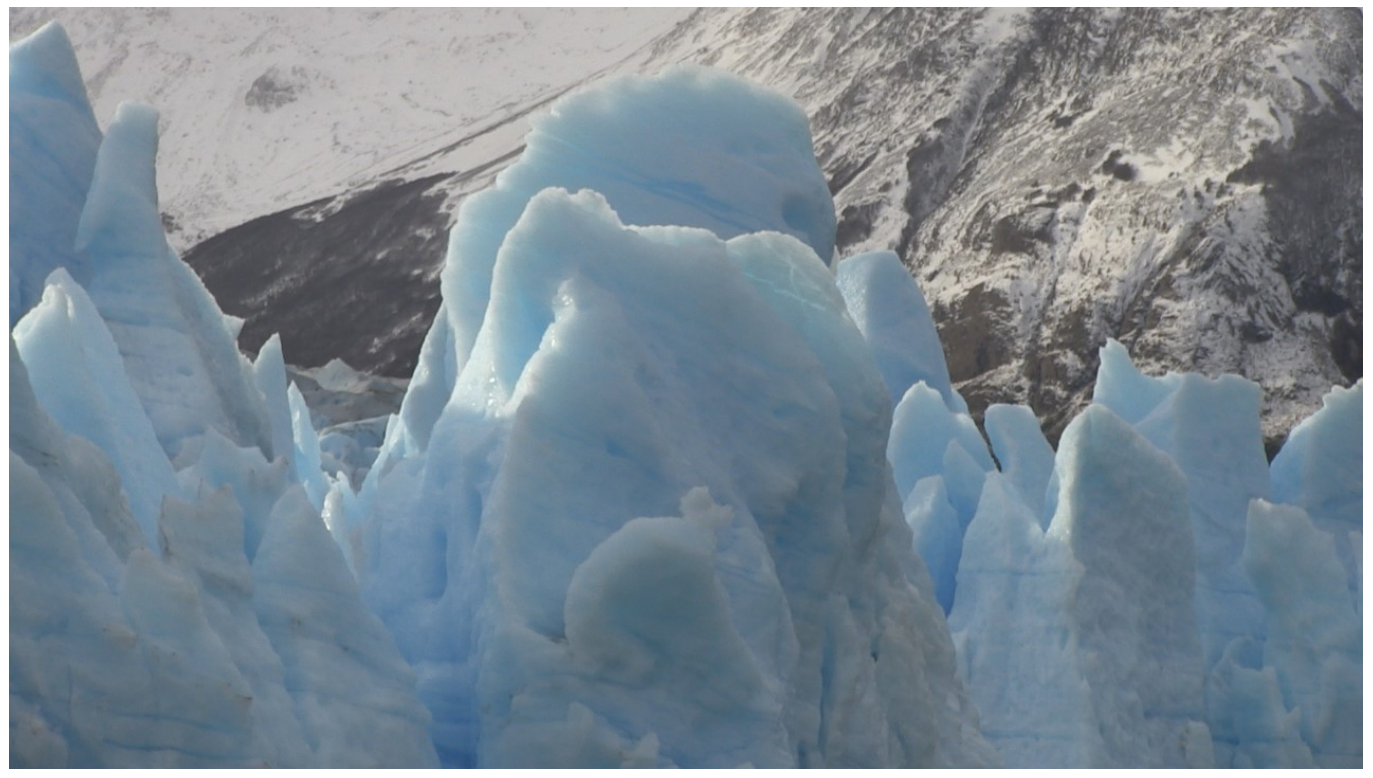

Guzmán's storytelling produces an atmosphere that is visually astonishing. He transforms the local or national history into a global story, the story of the planet earth. Nature is the background, the subject, the victim and also the one who stands, who stays: the light and the desert in Nostalgic for the light, the water and the sea 
in The Pearl Button, the mountains and the Andes in his forthcoming third film. Guzmán's trilogy is an esthetic and sensorial experience. Beauty has a purpose in this film, beauty connects humanity despite a history of violence. Or, precisely because of that history of violence, beauty becomes necessary to build resilience, to adapt to new circumstances and make something different without forgetting the family album.

\section{Genealogical memory}

This film transcends and goes deeper to aid in the understanding of history as one and multiple peoples at the same time, giving universal and cosmic meaning to a local history. Nostalgia for the Light briefly mentions some pivotal moments in Chile's history, but A Pearl Button goes deeper, explaining and connecting those episodes: the "communities of water" or first habitants of Patagonia and Tierra del Fuego, the indigenous populations that were exploited (in the construction, for example, of the railroads) and exterminated in the name of progress and civilization and later the killings during the years of the dictatorship.

The documentary begins with the history of the ancient inhabitants that occupied Chilean territory, more specifically western Patagonia, an area that includes the Gulf of Penas in the north and both banks of the Magellan Strait in the south. The first habitants of the Chilean Patagonia were different indigenous groups that dominated the water: the Kawésqar or Kaweskar (also called alacalufes septentrionales). They were ancient hunter-gatherer nomads ${ }^{7}$. They traveled through the different islands of the western area of Tierra del Fuego in their canoes, which were eight to nine meters long and one meter wide. They knew every islands, channels, islets, fjords, rivers and hills, giving names even to each small stream. Gabriela Paterito (Paáksa) is one of the few Kawésqar that is still alive. She has an important role in the film, Guzmán goes back and forth interviewing her. She explains she do not feel Chilean. She still speaks the language of her people. At

${ }^{7}$ According to the Chilean ethno-linguist Oscar Aguilera Faúndez in his interview with Amy Turner, which was published on the website of Cascada expediciones. 
some point in the movie the director gives her a list of words to translate to Kawesqar and when they arrive to the word God, she explains "No, not 'God'. We don't have that". She represents an historical disconnection between the modern world and the ancient world. Her knowledge about the sea, the islands and the Patagonia region is invaluable. Her world and the XXI century world, as shown by the narrator, never really stablished a bridge. Moreover the Chilean nation turn its back to the sea, is not really the natural source it should be and the young generations don't feel connected to it. In the film, the only role of the ocean shown in the modern times is as a cemetery.

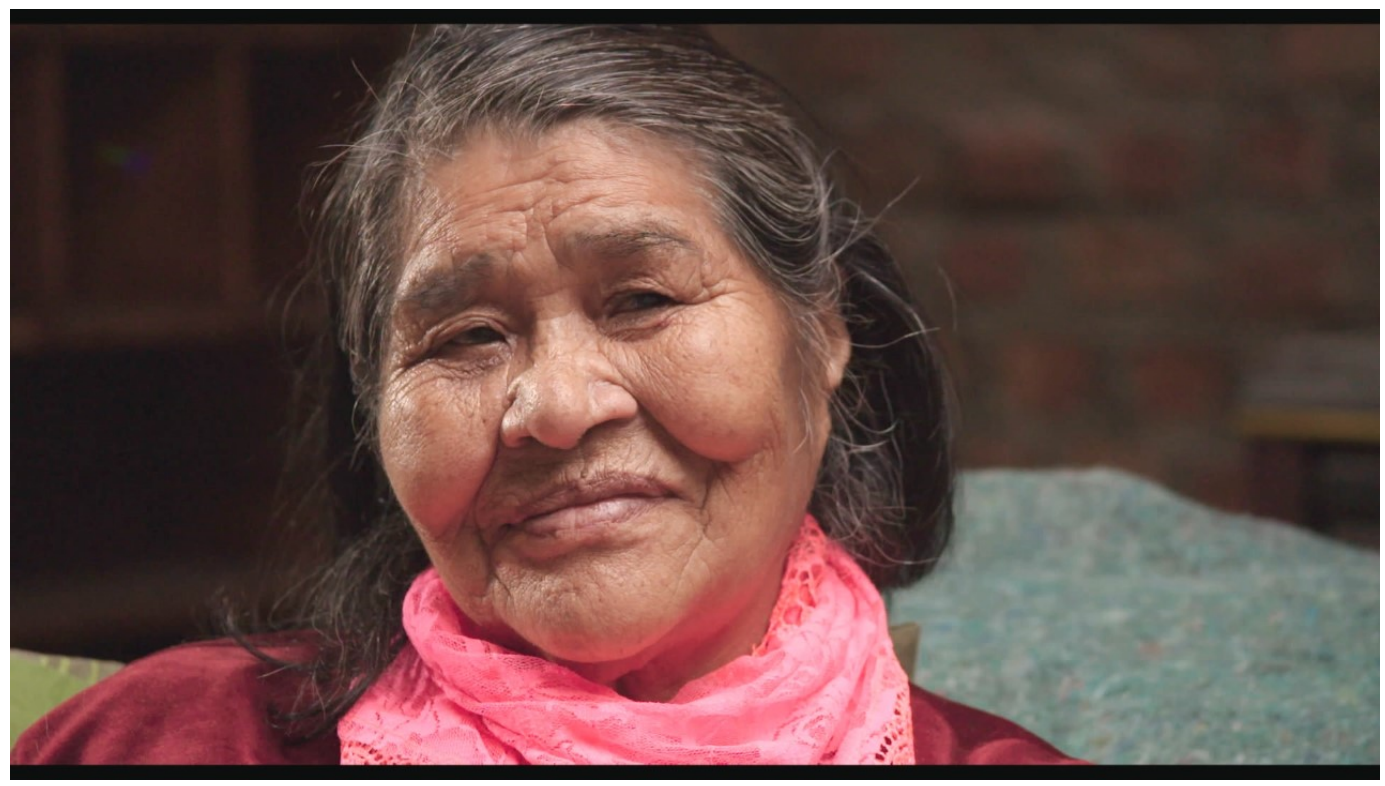

The artist Paz Errrázuriz had an exhibition in the Museo Nacional de Bellas Artes from September 10 to October 6 of 1996 where she presented the photographs of the faces of the Kawésqar that she was able to find. A picture of Gabriela taken for that exhibition is shown in the film and Guzmán explains how, thanks to the exhibition, he found Gabriela. This is the picture of that exhibition. 


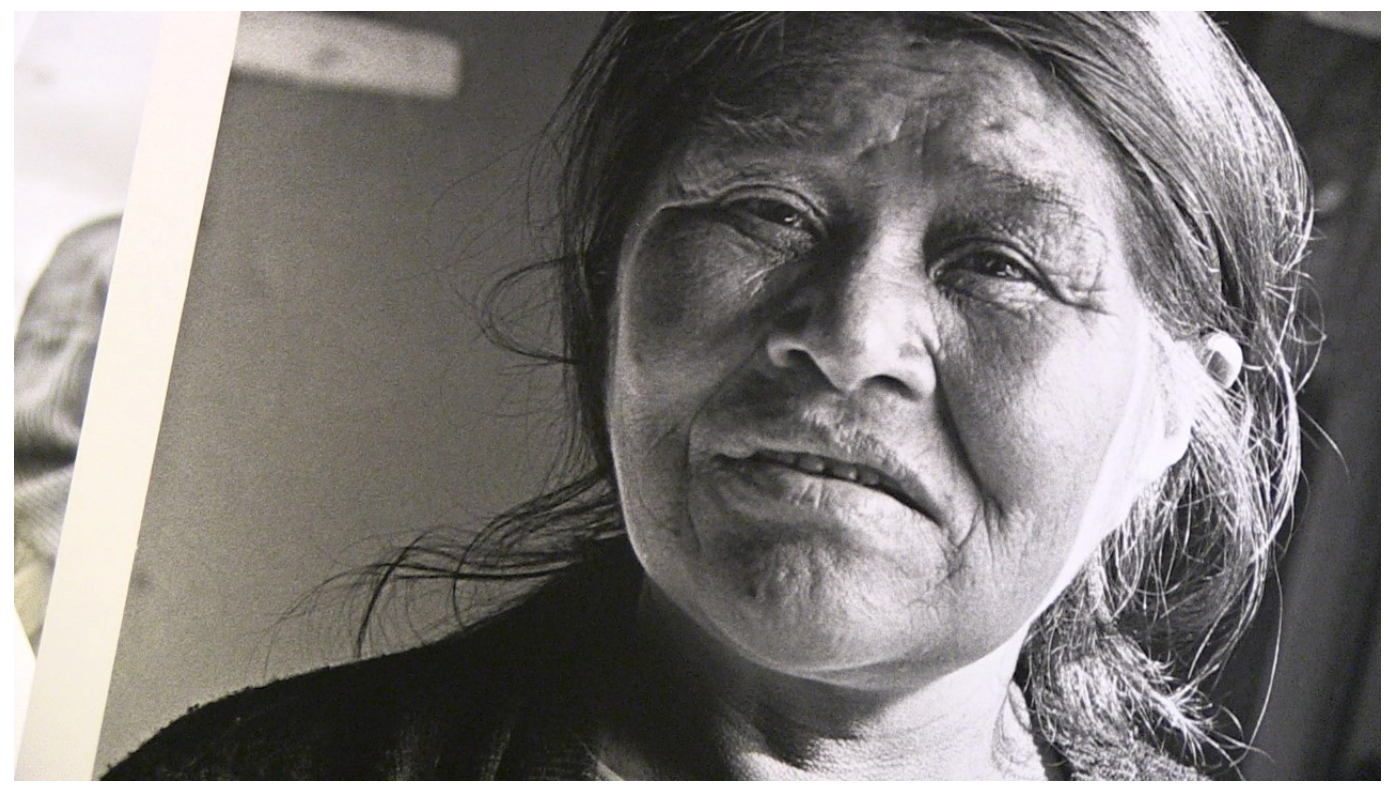

Gabriela describes her childhood and how she became skillful at harvesting shellfish, the base of their subsistence, from the sea. The Kawésqar were described by others as those that "walk under the sea". Is clear that the narrator wants to redeem them, give them a place in Chilean history as well as continental American history. He wants to pay tribute to their way of life and the respect they felt for the water, since their lives depended upon it. The historian Gabriel Salazar mentions, Chile has 4,200 kilometers of coast. Emphatically, Salazar sustains, "My country denies the Pacific Ocean." Even though the country has an extraordinary source of food, economy, means of transportation and potential trade tools, it has turned its back to the sea to focus on cattle raising, which results in the destruction of the land for harvesting and the "massacre of the indigenous populations."

After Gabriela's recollection, the movie take us to 1883 , the year when the colonizers, missionaries, gold diggers, Catholic Church and cattle ranchers started displacing and "civilizing" the indigenous populations. Through the narration of the different histories of Chile, and the populations that were oppressed and exterminated, there is a common denominator. The movie traces those links, those moments that reflect that different stories and voices are connected by a mystical unity. An example would be Dawson Island, an island in the Strait of Magellan that 
forms part of the Tierra del Fuego archipiélago. It was inhabited for thousands of years by different indigenous peoples, including the Kawésqar. In the late $19^{\text {th }}$ century the contact with Europeans began and the settlers started to dominate the region. With the development of large sheep ranches and the search for gold, Dawson Island was used as an internment camp for the Selknam and other native groups. It is estimated that in 15 years the population was reduced from 3000 to 500, which is why it is called the Selknam genocide. In 1890, the Chilean government used Dawson Island as a territory to "educate" and help the indigenous peoples assimilate into European-Chilean culture. After 1973, the same island was use by the military dictatorship of Pinochet to house political prisoners suspected of being communist activists. In the movie Guzmán reaffirms that in 16 years of dictatorship there were 800 detention centers with 3500 functionaries of the Pinochet government. According to the Report of the Chilean National Commission on Truth and Reconciliation, 99 people were being held prisoner on September 29, 1973, for political reasons. The cells were divided into three levels of punishment: prisoners on level one were allowed clothing and blankets; on level two they had no blankets, and on level three they had neither clothing nor blankets. The Dawson Island is a micro example of how places, stories and voices are connected. How locations for example can carry pivotal moments of a nation, a population and different civilizations.

Another example of how Guzmán establishes connections between the different histories and stories is the reference about how the same year Pinochet coup d'etat happened, a supernova was discovered in the sky. The mention of these two events responds to the mystic tone that the director wants to appeal to. As if those two events were connected and the supernova announces what was ahead in the history of Chile. A cosmic event suggest a political event, since in the logic the film is presenting the two are related. These kind of connections suggest a certain kind of redemption that didn't appear before in his other movies.

In A Pearl Button Guzmán will develop several of the topics he refer to in Nostalgia for the Light. In the first film, the narrator, Patricio Guzmán himself, 
poses questions that he attempts to answer in the second one. Among those questions is this one: How many secrets from the nineteenth century are still buried?: the extermination of the indigenous populations by the colonizers, the peasants that worked in the construction of the railroads and the trains, the civilizations that lived hundreds of years ago, among other stories. Memory and history are intertwined in this documentary, the history of Chile is connected to different stories and histories in time. In the film we see the faces and references to the victims that survived their stay in the Dawson Island when it was used as a camp by the military regime. Their memories are part of the Chilean history, which is multiple, told by the oppressors, the oppressed, the intellectuals, the workers, the history books at schools and so on. The memory is not linear but has different origins that are connected, all within the frame of human history and the history of the cosmos. Those origins are related to relations of power between different groups in different moments in history. There is not one point of departure but many different memories, histories and stories that are intertwined. Before, Guzmán's filmography was framed in a political history; in this new trilogy, that history is mixed with a "natural history" and a "cosmological history." Nature is the context and the protagonist of this history.

Besides the story of two surviving members of several native "water tribes" who thrived along Chilean waterways for thousands of years, Guzmán also tells the story of Jeremy or Jemmy Button, a native from the islands around Tierra del Fuego who was paid a button for being civilized by the Europeans. In 1830, he and two others were taken to England by Captain FitzRoy, who returned them home a year later. FitzRoy also took the young naturalist Charles Darwin with him, who wrote about Jemmy Button. Through this story, Guzmán extends the metaphor suggested by the film's title: not only is the button what is left from one of the victims of the Pinochet regime, it is the name the English gave to this native of Patagonia taken to Europe in exchange for a button. Here, a button is a commodity that allowed one person to buy another; elsewhere, a button made of pearl that comes from the sea and goes back to the sea on the body of a person. The life of that person was taken 
violently and the button is the trace of that life, a trace that tells a story. Guzmán tries to establish a connection with the viewer through a cultural object that takes the audience on a trip in time, an object so insignificant in everyday life but crucial in the message Guzmán wants to communicate. How is it that a pearl button can encapsulate the history of a nation, even the history of mankind? The button is a symbolic object, finding its echo in the traces left from the victims of Chile's military dictatorship, their corpses tied to heavy metal rail-tracks and dropped into the sea. Button is also the name the Europeans gave a native from Tierra del Fuego Province in 1830 and what they paid him for taking him to England. In both stories the button is a metaphor of oppression and violence.

The Pearl Button shows how the Pinochet regime trusted the water to get rid of the bodies that were tortured and killed by the military. Despite their confidence that the Pacific Ocean would rid them of the bodies, the water can wash away the crime but it can also bring it back, and that is what happened. Memory is resilient, and water as well. The last twenty minutes of the movie are dedicated to the story of Marta Lidia Ugarte Román. With enormous detail the movie explains how the bodies were attached to the railroad beams and which strategies they used to be sure the bodies would stay in the deep of the ocean. The lawyer of the family of Marta Lidia Ugarte Román dramatically insists that the eyes of the woman were preserved perfectly even through the conditions of the ocean and time, it was almost like she was still looking at the eyes of her perpetrators. Very likely, according to the exam that was made, she was still alive when they threw her body into the water. The picture of her face when her body was rescued is shown and confirms what the lawyer says.

Guzmán shows how the victims of the military junta were systematically tortured, killed and transformed in disposable bodies to be dropped in the sea. These vulnerable human bodies were used to ratify and maintain the power of the Chilean state. ${ }^{8}$ It appeared that the sea and the water were the best allies of the state but in

8 The idea of "disposable bodies" is used by Rachel Stein in her article "Disposable Bodies Biocolonialism in the "Constant Gardener" and "Dirty Pretty Things" ". Here she explains that 
the end the water betrayed the state. The bodies of thousands became disposable the moment the state threw them in the sea, there they were part of nature, became one with nature, but they didn't disappear, they came back through vestiges in the enormous pieces of wood to which they were chained. A systematic practice of the state transformed the victims bodies in disposable bodies, bodies that need it to be disappear in order to erase the evidence that can tie the crimes to the government. It was a secret state practice that was promoted by the government, at the time, and accepted by a large part of society.

The bodies of the natives from Patagonia were also disposable. In the mind of the colonizers they needed to be civilized, but the physical differences between culture and the physical bodies of the colonizer and the colonized made them become disposable, they were call "monsters," their differences became monstrosities. The bodies of those who disappeared under the military dictatorship were also disposable bodies by being taken into airplanes and thrown into the sea. The state ordered those actions and in that sense promoted a type of bio political regime that will not affect the whole population but that will "attack" those that were seen as a threat to the power of the state. The water literally and metaphorically brings back the bodies and allows the memory to be recovered.

\section{Conclusion}

Those bodies that the Pinochet regime thought would be disposable and disappear at the bottom of the sea came back. It seems water is not an accomplice after all and brought back the remains of the victims of the dictatorship. The bodies disappeared but some of the objects prevailed and carried the stories of those bodies. Through those objects the lives of the victims came to the surface and their individual stories became part of a broader national story.

Beauty and resilience take a central role in his production. It seems that at

biocolonialism uses/used exploitative practices by seeking vulnerable human bodies as natural resources to be consumed for the profit and pleasures of those with greater social and economic power, as evidenced by the transnational organ trade and the testing of pharmaceuticals. 
the end, after all the violence, the killings and the pain it is possible to bounce back from adversity. Resilience is a topic that recently has been discussed with more interest in fields like psychology, science, psychiatry, medicine and anthropology. ${ }^{9}$ However, it is a concept that has not been at the center of discussion of interdisciplinary studies and that needs to be evaluated in the light of different cultural productions like literature, film, visual arts, among others. The cinematographic production of the Chilean director Patricio Guzmán, about the years during the Chilean dictatorship and the post-dictatorship history of the country, shows a transition in his cinematographic view that gives the viewer an insight about the ways in which what I call a poetic of beauty can transform the interpretation of the past and the configuration of memory. What allows a society to remember is not only that they recognize the past, and in this case a violent past, it is part of their history and their own particular stories but how that history and those stories are part of the history of humanity, the planet and the entire galaxy. Resilience has a place in the impermanent character of everything and everyone. Everything is futile but not in vain. A meditation about beauty can heal the old scars.

In A Pearl Button, Guzmán's approach is determined by nature, history and poetic language. The movie emphasizes the disposable character of the bodies of the victims of the Pinochet regime that were thrown in the sea to delete the evidence that can bring the perpetrators to justice in the future. One way or the other, the water will bring them back. Although the flesh may not be there anymore, the viewer discovers that bones and objects from the victims might be brought back by the sea. The flow of the water is a reminder of history as a full circle of beginnings and endings, and in that sense the possibility of resilience when humans are confronted with adversity. The genealogical approach that Guzmán proposes in this movie, which entangles micro histories with the macro history of the cosmos,

\footnotetext{
${ }^{9}$ Steven M. Southwick et al. "Resilience and definitions, theory, and challenges: interdisciplinary perspectives" European Journal of Psychotraumatology 2014, 5: 25338. http://dx.doi.org/10.3402/eipt.v5.25338
} 
produces a complex narrative that opens possibilities and leaves the spectator with a sense of hope for a different future. When different historical events are put in the context of a macro history then resilience becomes possible.

\section{Bibliography}

Andemann, Jens., et al. A New Argentina and Brazilian Cinema, Palgrave Macmillan, 2013.

Avelar, Idelber. The Untimely Present: Postdictatorial Latin American Fiction and the Task of Mourning, NC: Duke University Press, 1999.

Blaine, Patrick., "Representing Absences In The Postdictatorial Documentary Cinema of Patricio Guzmán", Latin American Perspectives, 40, 1, 2013, pp. 114-130.

Burton, Julianne., The Social Documentary in Latin America. University of Pittsburgh Press, 1990.

Campo, Javier. "Documentary film from the southern cone during exile (19701980)", Latin American Perspectives, vol. 40, no. 1, 2013, pp. 145-60.

Dittus, Rubé., et al., "Cartografía del cine documental político chileno: entre el discurso político y la retórica audiovisual". Analisi. Quaderns de Comunicació i Cultura, 56, 2017, 33-47. Doi: https://ddd.uab.cat/pub/analisi/analisi_a2017n56/analisi_a2017n56p33.p df

Filmografía:

Guzmán, P. La Batalla de Chile/The Battle of Chile, USA: Icarus Films, 1995, 1976, 1979.

Chile, La Memoria Obstinada/Chile, Obstinate Memory, USA: Icarus Films, 1997. El Caso Pinochet/The Pinochet Case, USA: Icarus Films, 2001. 
CATEDRal Tomada: Revista literaria latinoamericana / Journal of Latin American Literary Criticism María del Pilar Melgarejo

Salvador Allende, USA: Icarus Films, 2004.

Nostalgia de la Luz/Nostalgia for the Light, USA: Icarus Films, [2010] 2011.

El Botón de Nacar/The Pearl Button, USA: Icarus Films, 2015.

The Pearl Button. Interviews with Patricio Guzmán.

http://www.newwavefilms.co.uk/assets/1156/The_Pearl_Button_Pressbo ok.pdf

Lee, K. B., "Berlin Review: Patricio Guzmán's 'The Pearl Button' is a Brillant Form of Documentary Art", 9 February 2015.

http://www.indiewire.com/2015/02/berlin-review-patricio-guzmans-thepearl-button-is-a-brilliant-form-of-documentary-art-65265/.

Martin-Jones, David. "Archival Landscapes and a Non-Anthropocentric 'Universe Memory'” Third Text. 27, 6, 2013, pp. 707-722.

Murphy, Kaitlin. M. "Remembering in ruins: Touching, seeing and feeling the past in Nostalgia de la luz/Nostalgia for the light [(2010)] 2011)", Studies in Spanish \& Latin American Cinemas, vol 13, no. 3, 2016, pp. 265-281.

Renov, Michael. "Toward a Poetics of Documentary". Theorizing Documentary. New York: Routledge/AFI, 1993, pp. 12-36.

Richard, Nelly. Residuos y metáforas: Ensayos de crítica cultural sobre la transición chilena. Santiago: Editorial Cuarto Propio, 1998.

Rodríguez, Juan Carlos. “Framing Ruins. Patricio Guzmán's Postdictatorial Documentaries". Latin American Perspectives. Vol 40. Issue 188, 2013pp. 131-144.

Ruiz Poveda-Vera, Cristina. "Historical Redemption in Patricio Guzmán's Nostalgia for the Light (2010)". Journal of Religion \& Film. Vol 21., Issue 2, 2017, pp.34-47.

The Pearl Button. Interviews with Patricio Guzmán. http://www.newwavefilms.co.uk/assets/1156/The_Pearl_Button_Pressbo ok.pdf 
CATEDRAL TomAdA: Revista de crítica literaria latinoamericana / Journal of Latin American Literary Criticism A Poetic of Beauty: Nature, Memory and Resilience in El Botón de Nacar/The Pearl Button (2015)

Traverso, Antonio. "Dictatorship memories: Working through trauma in Chilean post-dictatorship documentary". Continuum: Journal of Media \& Cultural Studies. Vol. 24, No. 1, 2010, pp. 179-191. 